\title{
Biotransformation of Sclareolide by Filamentous Fungi: Cytotoxic Evaluations of the Derivatives
}

\author{
Arturo Cano, ${ }^{a}$ María Teresa Ramírez-Apan ${ }^{b}$ and Guillermo Delgado*,b \\ ${ }^{a}$ Facultad de Estudios Superiores Zaragoza, Universidad Nacional Autónoma de México, \\ Av. Guelatao no. 66 (Eje 7 Oriente), Col Ejército de Oriente, Iztapalapa 09230, Mexico, D.F. \\ ${ }^{b}$ Instituto de Química, Universidad Nacional Autónoma de México, Ciudad Universitaria, \\ Circuito Exterior, Coyoacán 04510, Mexico, D.F.
}

\begin{abstract}
O esclareolido (1) foi incubado com oito diferentes espécies de fungos filamentosos usados convencionalmente para bio-oxidações. O composto 1 metabolizado pelo fungo Aspergilus niger

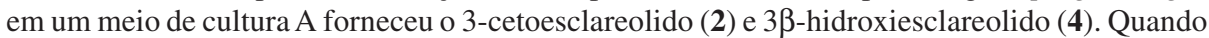
em um meio de cultura $B$ (mais rico em nutrientes em relação ao meio de cultura A), foram obtidos os compostos 2, 4, e ainda $3 \alpha, 6 \beta$-diidroxiesclareolido (16), 1-cetoesclareolido (17), 3-ceto-15-hidroxiesclareolido (18) e 3ß,15-diidroxiesclareolido (19). Os produtos 16-19 resultantes da biotransformação de 1 são relatados como substâncias inéditas. A fermentação de $\mathbf{1}$ com Cunninghamella blackesleeana usando o meio de cultura A forneceu os compostos 2 e 4, enquanto que empregando o meio de cultura $B$, forneceu os compostos 2, 4, 16 e 17. Os compostos 2, $\mathbf{4}$ e $\mathbf{1 7}$ foram obtidos também com Curvularia lunata. A biotransformação de $\mathbf{1}$ com Beauveria bassiana forneceu o composto 4 com rendimento satisfatório; com Rhizopus oligosporus e com Mucor miehei forneceu os compostos $\mathbf{2}$ e 4, enquanto que com R. nigricans and Fusarium moliniforme os compostos 2, 4 e 16 foram obtidos. A avaliação dos efeitos citotóxicos do composto 1 e dos produtos obtidos frente as linhagens de células cancerosas humanas selecionadas (U251, PC-3, K562, HCT-15, MCF-7 e SKUL-1) indicaram que o composto $16\left(3 \alpha, 6 \beta\right.$ - diidroxiesclareolido) apresenta um efeito citotóxico moderado $\left(\mathrm{IC}_{50}<100 \mu \mathrm{M}\right)$ contra a U251, a PC-3, a HCT-15 e a MCF-7.
\end{abstract}

Sclareolide (1) was incubated with eight different species of filamentous fungi conventionally used for bio-oxidations. Compound 1 was metabolized with Aspergillus niger in medium A to yield 3-ketosclareolide (2) and 3 $\beta$-hydroxysclareolide (4), while in medium B (containing major

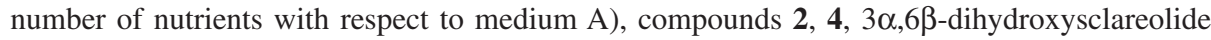
(16), 1-ketosclareolide (17), 3-keto-15-hydroxysclareolide (18) and 3 $\beta$,15-dihydroxysclareolide (19) were obtained. The biotransformation products 16-19 were found to be new substances. Fermentation of $\mathbf{1}$ with Cunninghamella blackesleeana using medium A afforded $\mathbf{2}$ and $\mathbf{4}$, while using medium B yielded 2, 4,16 and 17. Compounds 2, 4 and 17 were also obtained with Curvularia lunata. Biotransformation of $\mathbf{1}$ with Beauveria bassiana yielded $\mathbf{4}$ in satisfactory yield, with Rhizopus oligosporus and Mucor miehei afforded $\mathbf{2}$ and $\mathbf{4}$, while with $R$. nigricans and Fusarium moliniforme yielded 2, 4 and 16. Cytotoxic evaluation of $\mathbf{1}$ and the obtained products against selected human cancer cell lines (U251, PC-3, K562, HCT-15, MCF-7 and SKUL-1) indicated that 16 ( $3 \alpha, 6 \beta$-dihydroxysclareolide) displayed moderate cytotoxic $\left(\mathrm{IC}_{50}<100 \mu \mathrm{M}\right)$ against $\mathrm{U} 251$, PC-3, HCT-15 and MCF-7.

Keywords: biotransformation, sclareolide, filamentous fungi, microbiological oxidation

\section{Introduction}

The use of natural catalysts is now considered one of the most valuable routes for the synthesis of fine

*e-mail: delgado@unam.mx chemicals employing ecologically competitive procedures, particularly at industrial scale..$^{1-3}$ The selectivity and mildness of the biotransformations can be considered as advantages to similar, chemical-based methods ${ }^{4-6}$ and this is evident for the selective oxidation of non-activated carbon atoms which is difficult to achieve by classical organic 
chemistry. Biotransformations are typically carried out using either whole cells or isolated enzymes. Although in recent years some enzymes responsible for fungal hydroxylation have been isolated, whole-cell fermentation is the technique most often employed. ${ }^{7-9} \mathrm{~A}$ major challenge for the transformations using biocatalytic methods is to determine the appropriate microorganism and conditions, so, we proceeded with the screening using different fungal strains and media, with sclareolide (1, Figure 1 ) as substrate and then the processes were scaled up. In addition and in the search of new bioactive agents from natural products, ${ }^{10,11}$ the cytotoxic evaluation against several human tumor cell lines of $\mathbf{1}$ and the obtained products $(2,4,16-19)$ were carried up. Here we report our results.

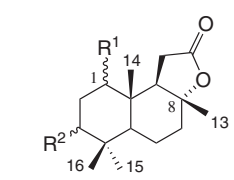

$1 \mathrm{R}^{1}=\mathrm{H}, \mathrm{R}^{2}=\mathrm{H}$

$3 \mathrm{R}^{1}=\mathrm{BOH}, \mathrm{R}^{2}=\mathrm{H}$

$4 \mathrm{R}^{1}=\mathrm{H}, \mathrm{R}^{2}=\mathrm{BOH}$

$6 \mathrm{R}^{1}=\alpha \mathrm{OH}, \mathrm{R}^{2}=\beta \mathrm{OH}$

$7 \mathrm{R}^{1}=\beta \mathrm{OH}, \mathrm{R}^{2}=\beta \mathrm{OH}$

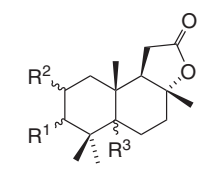

$8 \mathrm{R}^{1}=\mathrm{H}, \mathrm{R}^{2}=\alpha \mathrm{OH}, \mathrm{R}^{3}=\mathrm{H}$ $14 \mathrm{R}^{1}=\mathrm{H}, \mathrm{R}^{2}=\mathrm{H}, \mathrm{R}^{3}=\alpha \mathrm{OH}$

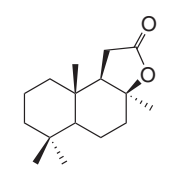

10

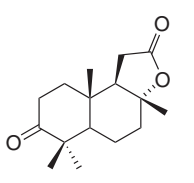

2

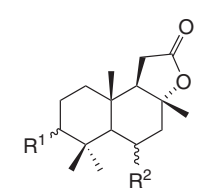

$5 \mathrm{R}^{1}=\beta \mathrm{OH}, \mathrm{R}^{2}=\beta \mathrm{OH}$ $12 \mathrm{R}^{1}=\alpha \mathrm{OH}, \mathrm{R}^{2}=\alpha \mathrm{OH}$ $16 \mathrm{R}^{1}=\alpha \mathrm{OH}, \mathrm{R}^{2}=\beta \mathrm{OH}$

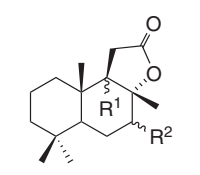

$13 \mathrm{R}^{1}=\mathrm{OH}, \mathrm{R}^{2}=\mathrm{H}$ $15 \mathrm{R}^{1}=\mathrm{H}, \mathrm{R}^{2}=\mathrm{BOH}$

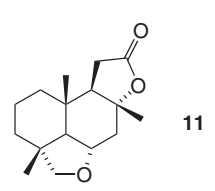
$9 \mathrm{R}^{1}=\beta O H, \mathrm{R}^{2}=\alpha O H, \mathrm{R}^{3}=\mathrm{H}$ gave 2, 4 and $3 \beta, 6 \beta$-dihydroxysclareolide $(\mathbf{5}) .^{18}$ The microbial transformation of $\mathbf{1}$ by Curvularia lunata yielded 2-4, 1 $\alpha, 3 \beta$-hydroxysclareolide (6) and $1 \beta, 3 \beta$-dihydroxysclareolide (7). ${ }^{19}$ The incubation of sclareolide with Cunninghamella elegans afforded 2, 4, 6 and 8-10. ${ }^{20}$ Cunninghamella blackesleeana metabolized compound 1 to afford 2, 5, 7 and 11-13. Biotransformation of $\mathbf{1}$ with C. echinulata yielded 5-hydroxysclareolide (14) and $7 \beta$-hydroxysclareolide (15). ${ }^{21}$

\section{Results and Discussion}

A preliminary screening and preparative bioconversion of 1 with eight fungal species showed a widespread capacity to transform the starting material into more polar products in different yields (Table 1), which were separated by vacuum column chromatography. ${ }^{22,23}$

Table 1. Yields (\%) of the isolated products of transformation of $\mathbf{1}$ with eight filamentous fungi ${ }^{a}$

\begin{tabular}{|c|c|c|c|c|c|c|c|}
\hline \multirow[b]{2}{*}{ Fungi } & \multicolumn{7}{|c|}{ Products $(\%)$} \\
\hline & $\mathbf{1}^{b}$ & 2 & 4 & 16 & 17 & 18 & 19 \\
\hline A. niger $^{c}$ & 6.5 & 22.7 & 37.4 & - & - & - & - \\
\hline A. niger ${ }^{d}$ & 2.8 & 11.7 & 27.7 & 5.9 & 10.1 & 12.4 & 9.4 \\
\hline C. blackesleeana ${ }^{c}$ & 6.5 & 18.8 & 57.3 & - & - & - & - \\
\hline C. blackesleeana ${ }^{d}$ & 5.3 & 7.2 & 20.6 & 28.3 & 8.7 & - & - \\
\hline C. lunata ${ }^{d}$ & 5.5 & 20.9 & 38 & - & 18.8 & - & - \\
\hline B. bassiana ${ }^{c}$ & 14.9 & - & 51.3 & - & - & - & - \\
\hline R. oligosporus ${ }^{c}$ & 17.3 & 12.1 & 32.1 & - & - & - & - \\
\hline$R$. nigricans $^{c}$ & 18.9 & 12.9 & 28.5 & 4.5 & - & - & -- \\
\hline M. miehei ${ }^{c}$ & 17.9 & 12.1 & 25.5 & - & - & - & - \\
\hline F. moliniforme ${ }^{c}$ & 10.3 & 16.1 & 28.9 & 32.3 & - & - & - \\
\hline
\end{tabular}

${ }^{a}$ Yields calculated after purification. ${ }^{b}$ Recovered starting material. ${ }^{c}$ Using culture medium A. ${ }^{d}$ Using culture medium B (see Experimental).

The crude organic extract obtained from incubation of sclareolide (1) with A. niger in culture medium A was separated by silica gel chromatographed to yield the known metabolites $\mathbf{2}$ and $\mathbf{4}$. However, when the same microorganism was grown in culture medium B (containing major number of nutrients with respect medium A), compounds $\mathbf{2}, \mathbf{4}$ and four new metabolites: 16-19 were obtained. Compound 2 was identified as the 3-ketosclareolide by comparison of its spectral data with those reported in the literature. ${ }^{17,19}$ The ${ }^{1} \mathrm{H}$ NMR spectrum of 4 (Table 2) revealed a signal at $\delta_{\mathrm{H}} 3.27\left(\mathrm{dd},{ }^{3} J 11,5 \mathrm{~Hz}\right.$, $1 \mathrm{H}$,) indicative of an axial proton at $\mathrm{C}-3\left(\delta_{\mathrm{C}} 78.6\right)$. The location of the hydroxyl group at $\mathrm{C}-3$ was confirmed on the basis of HMBC experiments and this compound was identified as $3 \beta$-hydroxysclareolide (4). ${ }^{17,19,20}$ Unambiguous and detailed ${ }^{1} \mathrm{H}$ NMR assignments (in comparison with previous reports ${ }^{17}$ ) are shown in Table 2. 
Table 2. ${ }^{1} \mathrm{H}$ and ${ }^{13} \mathrm{C}$ NMR data ( $\delta$ in ppm, multiplicite) of compounds 4, 16-19 (500 and $\left.125 \mathrm{MHz}, \mathrm{CDCl}_{3}\right)$. Coupling constants $(J$ in $\mathrm{Hz})$ in parenthesis

\begin{tabular}{|c|c|c|c|c|c|c|c|c|c|c|}
\hline \multirow[b]{2}{*}{ Position } & \multicolumn{2}{|l|}{4} & \multicolumn{2}{|l|}{16} & \multicolumn{2}{|l|}{17} & \multicolumn{2}{|l|}{18} & \multicolumn{2}{|l|}{19} \\
\hline & $\delta_{\mathrm{H}}$ & $\delta_{\mathrm{C}}$ & $\delta_{\mathrm{H}}$ & $\delta_{\mathrm{C}}$ & $\delta_{\mathrm{H}}$ & $\delta_{\mathrm{C}}$ & $\delta_{\mathrm{H}}$ & $\delta_{\mathrm{C}}$ & $\delta_{\mathrm{H}}$ & $\delta_{\mathrm{C}}$ \\
\hline \multirow[t]{2}{*}{1} & $\begin{array}{l}\beta_{\mathrm{ec}}: 1.19, \mathrm{ddd} \\
(13.5,13.5,4)\end{array}$ & 37.8 & $\begin{array}{c}\beta_{\mathrm{ec}}: 1.18, \mathrm{ddt} \\
(14,4,3.5)\end{array}$ & 37.1 & & 214.1 & $\beta_{\mathrm{ec}}: 1.74, \mathrm{~m}$ & 37.6 & $\beta_{\mathrm{ec}}: 1.47, \mathrm{~m}$ & 37.4 \\
\hline & $\alpha_{\mathrm{ax}}: 1.45 \mathrm{~m}$ & & $\begin{array}{c}\alpha_{\mathrm{ax}}: 1.68, \mathrm{ddd} \\
(14,14,4)\end{array}$ & & & & $\alpha_{\mathrm{ax}}: 1.62, \mathrm{~m}$ & & $\mathrm{H}-1 \alpha_{\mathrm{ax}}: 1.24, \mathrm{~m}$ & \\
\hline \multirow[t]{2}{*}{2} & $1.69, \mathrm{~m}$ & 26.8 & $\begin{array}{c}\beta_{\mathrm{ax}}: 1.48, \mathrm{ddd} \\
(14,4,3)\end{array}$ & 26.0 & $\begin{array}{c}\beta_{\mathrm{ax}}: 2.68, \mathrm{ddd} \\
(16,9,5)\end{array}$ & 34.5 & $\begin{array}{c}\beta_{\mathrm{ax}}: 2.67, \mathrm{ddd} \\
(17,13,7)\end{array}$ & 34.8 & $1.74-1.68, \mathrm{~m}$ & 26.4 \\
\hline & & & $\begin{array}{c}\alpha_{\mathrm{ec}}: 2.16, \mathrm{ddd} \\
(14.5,4,3)\end{array}$ & & $\begin{array}{c}\alpha_{\mathrm{ec}}: 2.29, \mathrm{ddd} \\
(16,8,4)\end{array}$ & & $\begin{array}{c}\alpha_{\mathrm{ec}}: 2.42, \mathrm{ddd} \\
(13,7,3)\end{array}$ & & $1.74-1.68, \mathrm{~m}$ & \\
\hline \multirow[t]{2}{*}{3} & $\begin{array}{l}\alpha_{\mathrm{ax}}: 3.27, \mathrm{dd} \\
\quad(11,5)\end{array}$ & 78.6 & $\begin{array}{c}\alpha_{a x}: 3.37, \mathrm{dd} \\
(3,3)\end{array}$ & 72.6 & $\alpha_{\mathrm{ax}}: 1.69, \mathrm{~m}$ & 39.2 & & 216.1 & $\begin{array}{l}\alpha_{\mathrm{ax}}: 3.70, \mathrm{dd} \\
\quad(10,5)\end{array}$ & 75.4 \\
\hline & & & & & $\beta_{\mathrm{ec}}: 1.84, \mathrm{~m}$ & & & & & \\
\hline 4 & & 38.8 & & 34.0 & & 32.4 & & 52.6 & & 42.0 \\
\hline 5 & $\begin{array}{c}\alpha_{\mathrm{ax}}: 1.89, \mathrm{dd} \\
\quad(11,3)\end{array}$ & 55.3 & $\alpha_{\mathrm{ax}}: 1.54, \mathrm{~d}$ & 50.3 & $\begin{array}{c}\alpha_{\mathrm{ax}}: 1.51, \mathrm{dd} \\
(12,3)\end{array}$ & 53.8 & $\begin{array}{l}\alpha_{\mathrm{ax}}: 2.04, \mathrm{dd} \\
\quad(10,2)\end{array}$ & 47.9 & $\alpha_{\mathrm{ax}}: 1.11, \mathrm{~m}$ & 49.6 \\
\hline \multirow[t]{2}{*}{6} & $\beta_{\mathrm{ax}}: 1.47, \mathrm{~m}$ & 20.3 & $\begin{array}{c}\alpha_{\mathrm{ec}}: 4.70, \mathrm{ddd} \\
(3,3,3)\end{array}$ & 69.0 & $\begin{array}{c}\beta_{\text {ax: }}: 1.59, \text { dddd } \\
(12,12,12,3)\end{array}$ & 21.1 & $\beta_{\mathrm{ax}}: 2.13, \mathrm{~m}$ & 37.7 & $1.49-1.41, \mathrm{~m}$ & 20.2 \\
\hline & $\alpha_{\mathrm{ec}}: 1.89, \mathrm{~m}$ & & & & $\alpha_{\mathrm{ec}}: 1.90 \mathrm{~m}$ & & $\alpha_{\mathrm{ec}} 2.13, \mathrm{~m}$ & & $1.74-1.68, \mathrm{~m}$ & \\
\hline \multirow[t]{2}{*}{7} & $\begin{array}{c}\beta_{\mathrm{ec}}: 2.09, \text { ddd } \\
(12,3.5,3.5)\end{array}$ & 38.4 & $\begin{array}{c}\beta_{\mathrm{ec}}: 2.04, \mathrm{dd} \\
\quad(13,4)\end{array}$ & 46.7 & $\begin{array}{c}\beta_{\mathrm{ec}}: 2.08, \text { ddd } \\
\quad(12,3,3)\end{array}$ & 37.2 & $\beta_{\mathrm{ec}}: 1.65, \mathrm{~m}$ & 21.0 & $\beta_{\mathrm{ec}}: 2.10-2.05, \mathrm{~m}$ & 38.2 \\
\hline & $\alpha_{\mathrm{ax}}: 1.64, \mathrm{~m}$ & & $\begin{array}{c}\alpha_{\text {ax }}: 1.95, \mathrm{dd} \\
\quad(13,3)\end{array}$ & & $\alpha_{\mathrm{ax}}: 1.68, \mathrm{~m}$ & & $\mathrm{H}-7 \alpha_{\mathrm{ax}}: 1.80, \mathrm{~m}$ & & $\alpha_{\mathrm{ax}}: 1.74-1.68, \mathrm{~m}$ & \\
\hline 8 & & 86.1 & & 86.3 & & 85.6 & & 85.6 & & 85.9 \\
\hline 9 & $\begin{array}{c}\alpha_{\mathrm{ax}}: 1.92, \mathrm{dd} \\
(15,6.5)\end{array}$ & 58.9 & $\begin{array}{c}\alpha_{\mathrm{ax}}: 2.58, \mathrm{dd} \\
(14,7 \mathrm{~Hz})\end{array}$ & 51.8 & $\begin{array}{c}\alpha_{\text {ax }}: 2.16, \mathrm{dd} \\
\quad(14,7)\end{array}$ & 52.0 & $\begin{array}{c}\alpha_{\mathrm{ax}}: 2.07, \mathrm{dd} \\
\quad(15,7)\end{array}$ & 58.1 & $\begin{array}{c}\alpha_{\mathrm{ax}}: 1.95, \mathrm{dd} \\
\quad(16,7)\end{array}$ & 58.9 \\
\hline 10 & & 35.8 & & 39.7 & & 49.7 & & 35.5 & & 35.8 \\
\hline \multirow[t]{2}{*}{11} & $\begin{array}{c}\beta_{\mathrm{ax}}: 2.42, \mathrm{dd} \\
(16,15)\end{array}$ & 28.7 & $\begin{array}{c}\beta_{\mathrm{ax}},: 2.46, \mathrm{dd} \\
(16,14)\end{array}$ & 28.5 & $\begin{array}{c}\beta_{\text {ax }}: 2.96, \mathrm{dd} \\
(17,14)\end{array}$ & 30.8 & $\begin{array}{c}\beta_{\mathrm{ax}}: 2.49, \mathrm{dd} \\
\quad(16,15)\end{array}$ & 28.6 & $\begin{array}{c}\beta_{\mathrm{ax}}: 2.42, \mathrm{dd} \\
(16,15)\end{array}$ & 28.7 \\
\hline & $\begin{array}{c}\alpha_{\mathrm{ec}}: 2.24, \mathrm{dd} \\
\quad(16,6.5)\end{array}$ & & $\begin{array}{c}\alpha_{\mathrm{ec}}: 2.34, \mathrm{dd} \\
\quad(16,7)\end{array}$ & & $\begin{array}{c}\alpha_{\mathrm{ec}}: 2.53, \mathrm{dd} \\
\quad(17,7)\end{array}$ & & $\begin{array}{l}\alpha_{\mathrm{ec}}: 2.31, \mathrm{dd} \\
\quad(16,7)\end{array}$ & & $\begin{array}{l}\alpha_{\mathrm{ec}}: 2.25, \mathrm{dd} \\
\quad(16,7)\end{array}$ & \\
\hline 12 & & 175.5 & & 177.1 & & 176.7 & & 175.8 & & 176.3 \\
\hline 13 & $1.34, \mathrm{~s}$ & 21.5 & $1.59, \mathrm{~s}$ & 23.0 & $1.35, \mathrm{~s}$ & 21.7 & $1.41, \mathrm{~s}$ & 21.3 & $1.34, \mathrm{~s}$ & 21.5 \\
\hline 14 & $0.93, \mathrm{~s}$ & 15.1 & $1.29, \mathrm{~s}$ & 16.9 & $1.19, \mathrm{~s}$ & 14.4 & $1.13, \mathrm{~s}$ & 14.7 & $0.97, \mathrm{~s}$ & 15.4 \\
\hline \multirow[t]{2}{*}{15} & $1.01, \mathrm{~s}$ & 27.9 & $1.04, \mathrm{~s}$ & 32.4 & $1.03, \mathrm{~s}$ & 31.3 & $\begin{array}{c}\mathrm{H}-15_{\mathrm{a}}: 3.76, \mathrm{~d} \\
\text { (11) }\end{array}$ & 66.6 & $\begin{array}{c}\mathrm{H}-15_{\mathrm{a}}: 3.72 \\
\quad(10.5)\end{array}$ & 70.9 \\
\hline & & & & & & & $\begin{array}{c}\mathrm{H}-15_{\mathrm{b}}: 3.39, \mathrm{~d} \\
\text { (11) }\end{array}$ & & $\begin{array}{c}\mathrm{H}-15_{\mathrm{b}}: 3.43, \mathrm{~d} \\
\quad(10.5)\end{array}$ & \\
\hline 16 & $0.81, \mathrm{~s}$ & 15.0 & $1.21, \mathrm{~s}$ & 23.5 & $1.06, \mathrm{~s}$ & 23.2 & $1.00, \mathrm{~s}$ & 16.3 & $0.88, \mathrm{~s}$ & 11.2 \\
\hline
\end{tabular}

For compound 16, the HRFABMS established a molecular formula of $\mathrm{C}_{16} \mathrm{H}_{26} \mathrm{O}_{4}[\mathrm{M}+\mathrm{H}]^{+}$, at $\mathrm{m} / z$ 283.1915, calculated for $\left(\mathrm{C}_{16} \mathrm{H}_{26} \mathrm{O}_{4}+\mathrm{H}\right)$ 283.1909. The ${ }^{1} \mathrm{H}$ NMR spectrum revealed two signals at $\delta_{\mathrm{H}} 3.37\left(\mathrm{dd},{ }^{3} \mathrm{~J} 3,3 \mathrm{~Hz}\right.$, $1 \mathrm{H})$ and $\delta_{\mathrm{H}} 4.70\left(\mathrm{ddd},{ }^{3} J 3,3,3 \mathrm{~Hz}, 1 \mathrm{H}\right)$, indicative of two equatorial hydrogens at C-3 $\left(\delta_{\mathrm{C}} 72.6\right)$ and C-6 $\left(\delta_{\mathrm{C}} 69.0\right)$, respectively. The locations of the hydroxyl groups at $\mathrm{C}-3$ and C-6 in $\mathbf{1 6}$ were determined on the basis of HMBC experiments, in particular by the $16 \mathrm{CH}_{3}-\left(\delta_{\mathrm{H}} 1.21\right)$ and the $15 \mathrm{CH}_{3}-\left(\delta_{\mathrm{H}} 1.04\right)$ crosspeaks with $\mathrm{C}(3)\left(\delta_{\mathrm{C}} 72.6\right)$ and the crosspeaks between $\mathrm{H}-6\left(\delta_{\mathrm{H}} 4.70\right)$ and $\mathrm{C}-4\left(\delta_{\mathrm{C}} 34.0\right), \mathrm{C}-5$ $\left(\delta_{\mathrm{C}} 50.3\right), \mathrm{C}-10\left(\delta_{\mathrm{C}} 39.7\right), \mathrm{C}-7\left(\delta_{\mathrm{C}} 46.7\right)$, and C-8 $\left(\delta_{\mathrm{C}} 86.3\right)$. COSY, HMQC and NOESY experiments allowed complete assignments for all protons and carbons (Table 2) and the structure was confirmed as $3 \alpha, 6 \beta$-dihydroxysclareolide (16). The epimer at $\mathrm{C}(3)$ has been reported previously. ${ }^{18}$
The new metabolite $\mathbf{1 7}$ was obtained as a white crystalline solid. Its HRFABMS exhibited $[\mathrm{M}+\mathrm{H}]^{+}$at $\mathrm{m} / z, 265.1805$, corresponding to the molecular formula $\mathrm{C}_{16} \mathrm{H}_{25} \mathrm{O}_{3}$ (calculated for $\mathrm{C}_{16} \mathrm{H}_{24} \mathrm{O}_{3}+\mathrm{H}:$ 265.1804). The IR spectral data displayed absorptions for $\gamma$-lactone $\left(1774 \mathrm{~cm}^{-1}\right)$ and ketone $\left(1708 \mathrm{~cm}^{-1}\right)$. These data were similar to those for compound $2 . .^{17,18}$ The ${ }^{13} \mathrm{C}$ NMR data (Table 2) showed resonances for sixteen carbons and the DEPT experiments established the multiplicity for each carbon signal and they revelead the presence of four methyls, five methylenes, two methines and five quaternary carbons. The ${ }^{1} \mathrm{H}$ NMR $(500 \mathrm{MHz}$ ) data of $\mathbf{1 7}$ (Table 2) showed singlets at $\delta_{\mathrm{H}} 1.35,1.19,1.03$ and 1.06 which were assigned to $13 \mathrm{CH}_{3}-, 14 \mathrm{CH}_{3}-, 15 \mathrm{CH}_{3}-$ and $16 \mathrm{CH}_{3}-$, respectively, by direct comparison with similar compounds. In particular, $13 \mathrm{CH}_{3}-$ is located downfield $\left(\delta_{\mathrm{H}} 1.35\right)$ due to it is linked to the carbon closing the $\gamma$-lactone (C-8) and the signal at $\delta_{\mathrm{H}} 1.19$, which 
showed NOESY crosspeak with $\mathrm{H}-11 \beta\left(\delta_{\mathrm{H}} 2.96\right)$ and $\mathrm{HMBC}$ crosspeak with the signal at $\delta_{\mathrm{C}} 52.00(\mathrm{C}-9)$ was assigned to $14 \mathrm{CH}_{3}-$. The location of the ketone at $\mathrm{C}-1$ was determined by the HMBC crosspeak of the signal at $\delta_{\mathrm{H}} 1.19\left(14 \mathrm{CH}_{3}-\right)$ with the resonance at $\delta_{\mathrm{C}} 214.1$. Assignments for all hydrogens and carbons were done by COSY, HMQC, HMBC and NOESY experiments.

Compound 18 was obtained as white crystalline solid and its IR spectral data displayed absorptions at $3459(\mathrm{O}-\mathrm{H})$, $1773(\mathrm{C}=\mathrm{O})$ and $1174(\mathrm{C}-\mathrm{O}) \mathrm{cm}^{-1}$. The HREIMS exhibited $[\mathrm{M}+\mathrm{H}]^{+}$at $m / z, 281.1751$ establishing the molecular formula $\mathrm{C}_{16} \mathrm{H}_{24} \mathrm{O}_{4}$ (calculated for $\mathrm{C}_{16} \mathrm{H}_{24} \mathrm{O}_{4}+\mathrm{H}: 281.1753$ ). The ${ }^{13} \mathrm{C}$ NMR spectrum of $\mathbf{1 8}$ (DEPT experiment) displayed resonances for sixteen carbon atoms, including three methyls, six methylenes, two methines and five quaternary carbons. Its ${ }^{1} \mathrm{H}$ NMR spectrum $\left(\mathrm{CDCl}_{3}, 500 \mathrm{MHz}\right)$ showed three singlets at $\delta_{\mathrm{H}} 1.41,1.13$ and 1.00 due the $\mathrm{H}-13, \mathrm{H}-14$ and H-16 methyls, respectively, due to the observed NOESY crosspeaks between $\mathrm{C}-13$ and $\mathrm{C}-14$ and between $\mathrm{C}-14$ with C-16. A notable difference with the 4,4'-dimethyl products was the absence of one methyl group and the presence of an AB system $\left(\delta_{\mathrm{H}} 3.76\right.$ and $\left.3.39,{ }^{2} J 11 \mathrm{~Hz}\right)$, which was assigned to the methylene protons at $\mathrm{C}-15\left(\delta_{\mathrm{C}} 66.6\right)$. The signal at $\delta_{\mathrm{C}} 216.1$ corresponds to a ketone carbonyl located at $\mathrm{C}-3$ due to $\mathrm{HMBC}$ correlations of this carbon with the $\mathrm{AB}$ system $\left(\mathrm{H}-15_{\mathrm{a}}\right.$

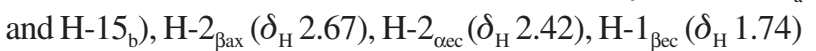
and with $16 \mathrm{CH}_{3}-\left(\delta_{\mathrm{H}} 1.00\right)$. The ${ }^{1} \mathrm{H}$ and ${ }^{13} \mathrm{C}$ NMR chemical shifts assigments for compound $\mathbf{1 8}$ (Table 2), confirmed this compound as 3-keto-15-hydroxysclareolide.

The other novel biotransformation product, $\mathbf{1 9}$, was a crystalline solid. The IR spectral data displayed absorptions at $3489(\mathrm{O}-\mathrm{H})$ and $1767(\mathrm{C}=\mathrm{O}) \mathrm{cm}^{-1}$. The HREIMS of 19 exhibited a molecular ion $\mathrm{m} / \mathrm{z}, 283.1908$ corresponding to the molecular formula $\mathrm{C}_{16} \mathrm{H}_{26} \mathrm{O}_{4}$ (calculated for $\left.\mathrm{C}_{16} \mathrm{H}_{26} \mathrm{O}_{4}+\mathrm{H}: 283.1909\right)$. The ${ }^{13} \mathrm{C}$ NMR spectrum of 19 showed resonances for sixteen carbons including three methyls, six methylenes, three methines and four quaternary carbons. The ${ }^{1} \mathrm{H}$ NMR data of $\mathbf{1 9}$ (Table 2) showed singlets at $\delta_{\mathrm{H}} 1.34,0.97$ and 0.88 , assigned to $13 \mathrm{CH}_{3}-, 14 \mathrm{CH}_{3}-$, $16 \mathrm{CH}_{3}-$, respectively, by comparison with the above described substances. Additionally, the signals at $\delta_{\mathrm{H}} 3.72$ and $3.43\left({ }^{2} J 10,5 \mathrm{~Hz}\right)$ established the presence of an $\mathrm{AB}$ system for the hydroxymethylene protons located at C-15 $\left(\delta_{\mathrm{C}} 70.9\right)$ which overlapped with a doublet of doublet signal corresponding to $\mathrm{H}-3_{\text {cax }}\left(\delta_{\mathrm{H}} 3.70,{ }^{3} \mathrm{~J} 10,5 \mathrm{~Hz}\right)$. The signal at $\delta_{\mathrm{C}} 75.4$, assigned to $\mathrm{C}-3$, showed $\mathrm{HMBC}$ correlations with the $\mathrm{AB}$ system for $\mathrm{H}-15_{\mathrm{a}}$ and $\mathrm{H}-15_{\mathrm{b}}$, and with $16 \mathrm{CH}_{3}-$ $\left(\delta_{\mathrm{H}} 0.88\right)$. Assignments for all hydrogens and carbons for compound 19 were done by COSY, HMQC, HMBC and NOESY experiments and verified its structure as $3 \beta, 15-$ dihydroxysclareolide (Table 2).
An interesting variety of products and yields were obtained by the biotransformation of sclereolide (1) with different fungi. The transformation of $\mathbf{1}$ with A. niger in medium A (containing minor number of nutrients) produced $\mathbf{2}$ and $\mathbf{4}$, while using medium $B$ yielded six compounds $(\mathbf{2}, \mathbf{4}, \mathbf{1 6}-19)$ in variable yields (from $5.9 \%$ to $27.1 \%$ ), affording a keto group at C-1 (17) for the first time. Using medium B with A. niger, C. blackesleeana and C. lunata yielded various products in relatively variable yields, while medium A produced fewer products, with better yields though (see Table 1). The transformation of $\mathbf{1}$ with $B$. bassiana afforded exclusively product $\mathbf{4}$ in acceptable yield (51.3\%), in comparison with other biotransformations. ${ }^{24}$ These results gave additional evidences of the importance of the species, strains and media employed in the structural diversity of the products and the yields of the biotransformations.

Sclareolide (1) and derivatives 2, 4, 16-19 were tested for in vitro cytotoxic activity against human cancer cell lines U251 (central nervous system), PC-3 (prostate cancer), K562 (leukemia), HCT-15 (colon), MCF-7 (breast) and SKUL-1 (lung) following standard procedures. ${ }^{25}$ Compound $\mathbf{1}$ displayed activity against PC-3 tumor cell line $\left(\mathrm{IC}_{50} 71.12 \pm 4.7 \mu \mathrm{M}\right)$ and 16 displayed activity against $\mathrm{U} 251\left(\mathrm{IC}_{50} 87.40 \pm 5.4 \mu \mathrm{M}\right), \mathrm{PC}-3$ $\left(\mathrm{IC}_{50} 34.47 \pm 7.4 \mu \mathrm{M}\right), \mathrm{HCT}-15\left(\mathrm{IC}_{50} 92.23 \pm 4.2 \mu \mathrm{M}\right)$, MCF-7 $\left(\mathrm{IC}_{50} 89.11 \pm 2.4 \mu \mathrm{M}\right)$. All the other $\mathrm{IC}_{50}$ values were above a $100 \mu \mathrm{M}$ and were considered not active. ${ }^{25}$ It is interesting that the presence of the hydroxyl groups at C- $3 \alpha$ and C-6 6 increased the cytotoxicity with respect to the starting material (1).

\section{Experimental}

\section{General experimental procedures}

Melting points were determined on a Fischer-Jones apparatus. Optical rotation were measured on a Perkin-Elmer 341 polarimeter. Infrared spectra are registred Nicolet Magna FT-IR 750 spectrometer. ${ }^{1} \mathrm{H}$ and ${ }^{13} \mathrm{C}$ NMR spectra were taken on a Varian Unity-plus 500 (at 500 and $125 \mathrm{MHz}$ ) instrument. EI-MS: Jeol JMS-AX505HA mass spectrometer and Jeol JMS-SX 102 A) for HREIMS. TLC spots were revealed by spraying with ceric ammonium sulfate, followed by heating. Vacuum column chromatographies were done following the reported procedures. ${ }^{22,23}$ Column chromatography (CC) were performed using silica gel $70-230$, TLC using silica gel $60 \mathrm{~F}_{254}$ (Merck) plates and preparative TLC using silica gel $60 \mathrm{~F}_{254}$ (Merck) Plates. Sclareolide was purchased from Sigma-Aldrich.

\section{Microorganisms}

A. niger (ATCC 16404), B. bassiana (ATCC 13144), C. blackesleeana (ATCC 8688a), C. lunata (ATCC 13432), 
F. moliniforme (ATCC 10209), M. miehei (ATCC 16457), R. oligosporus (ATCC 22959), R. nigricans (ATCC 6227b), were obtained from the Instituto de Biotecnología, Universidad Nacional Autónoma de México, maintained on potato dextrose agar (PDA) and stored at $4{ }^{\circ} \mathrm{C}$.

\section{Media and culture conditions}

The media were prepared by mixing the following ingredients in $1 \mathrm{~L}$ of distilled water. Medium A (YEPGA): $(10 \mathrm{~g})$ peptone, $(10 \mathrm{~g})$ yeast extract, $(10 \mathrm{~g})$ beef extract and $(50 \mathrm{~g})$ glucose. The $\mathrm{pH}$ was adjusted to $7\left(\mathrm{NaOH} 1 \mathrm{~mol} \mathrm{~L}^{-1}\right)$ before autoclaving. Medium B was prepared by mixing the following ingredients: glucose $(10 \mathrm{~g})$, glycerol $(10 \mathrm{~g})$, peptone $(5 \mathrm{~g})$, yeast extract $(5 \mathrm{~g}), \mathrm{KH}_{2} \mathrm{PO}_{4}(5 \mathrm{~g})$ and $\mathrm{NaCl}(5 \mathrm{~g})$ at $\mathrm{pH} 7$ (adjusted with $\mathrm{NaOH} 1 \mathrm{~mol} \mathrm{~L}^{-1}$ ) for A. niger, C. blackesleeana, C. lunata.

\section{Incubation experiments}

Firstly, the eight fungi were tested for their ability to metabolize 1 on the analytical scale (10 to $15 \mathrm{mg}$ of substrate, $25 \mathrm{~mL}$ medium culture), and then the same biotransformation experiments were carried out on preparative scale (150 to $310 \mathrm{mg}$ ). Both analytical and preparative biotransformations were conducted following similar procedures. Erlenmeyer flasks $(250 \mathrm{~mL})$ containing $125 \mathrm{~mL}$ of medium A or the medium B were inoculated with a dense suspension $(2 \mathrm{~mL})$ of the corresponding fungi. Incubations were maintained at $25^{\circ} \mathrm{C}$ with gyratory shaking $(125 \mathrm{rpm})$ for $24 \mathrm{~h}$ (A. niger, R. nigricans, R. oligosporus, M. miehei), $48 \mathrm{~h}$ (F. moniliforme) or $72 \mathrm{~h}$ (C. blackesleeana, C. lunata, B. bassiana). Then, the substrates in acetone $(5-10 \mathrm{~mL})$ were added and the process continued for 14 days. These biotransformation experiments were monitored by TLC, including two controls, a "culture control" and a "substrate control" to eliminate the possibility that the isolated products were microbial secondary metabolites and/or that the culture media did not perform any chemical transformation on the substrate.

\section{Recovery and purification of metabolites}

Cultures were filtered and fungal cells were washed thoroughly with water and the filtrate and washings were combined, saturated with $\mathrm{NaCl}$ and extracted with $\mathrm{CH}_{2} \mathrm{Cl}_{2}$ (three times). The organic extracts were combined, dried with $\mathrm{Na}_{2} \mathrm{SO}_{4}$ and evaporated under reduced pressure. The organic residues were subjected to chromatography by VCC using gradient elution system with hexane/EtOAc. CC and preparative TLC allowed the final purification of the compounds.

\section{Biotransformation of 1 by A. niger in medium $A$}

After $24 \mathrm{~h}$ of inoculation with a dense suspension of the spores of A. niger, 20 erlenmeyer flask cultures (YEPGA) received $204.3 \mathrm{mg}$ of sclareolide (1) in $10 \mathrm{~mL}$ of acetone. After incubation for 14 days the cultures were processed as indicated above to yield a crude dark oily residue (194.3 mg). Column chromatography of the organic extract yielded 3-ketosclareolide (2, $44.2 \mathrm{mg}, 22.7 \%)$, $3 \beta$-hydroxysclareolide $(\mathbf{4}, 72.7 \mathrm{mg}, 37.4 \%)$ and sclareolide (1, $12.6 \mathrm{mg}, 6.5 \%)$.

\section{Biotransformation of 1 by A. niger in medium B}

The substrate $\mathbf{1}(210 \mathrm{mg})$ was dissolved in acetone $(10 \mathrm{~mL})$, distributed among 20 erlenmeyer flask cultures (medium B), previously (24h) inoculated with a dense suspension of spores of A. niger. The biotransformation was allowed to proceed for 14 days and the cultures were processed as indicated above to obtain starting material 1 (6 mg, 2.8\%), 2 (24.5 mg, 11.7\%), 4 (58.2 mg, 27.7\%), 16 (22.4 mg, 5.9\%), 17 (21.2 mg, 10.1\%) $\mathbf{1 8}$ (26 mg, 12.4\%) and $\mathbf{1 9}$ (19.7 mg, 9.4\%).

$3 \alpha, 6 \beta$-Dihydroxysclareolide (16): mp. $188-190^{\circ} \mathrm{C}$; $[\alpha]_{\mathrm{D}}^{25}+30.3\left(c 0.30, \mathrm{CHCl}_{3}\right)$; IR $v_{\max } / \mathrm{cm}^{-1}\left(\mathrm{CHCl}_{3}\right): 3618$, 2933, 1758; ${ }^{1} \mathrm{HNMR}\left(\mathrm{CDCl}_{3}, 500 \mathrm{MHz}\right)$ and ${ }^{13} \mathrm{CNMR}\left(\mathrm{CDCl}_{3}\right.$, $125 \mathrm{MHz})$ : see Table 2; HRFABMS [M+H] ${ }^{+}$Found: 283.1915. Calc. for $\mathrm{C}_{16} \mathrm{H}_{26} \mathrm{O}_{4}+\mathrm{H}$ : 283.1909; EIMS m/z 267 (24\%), 249 (56), 169 (83), 43 (100).

1-Ketosclareolide (17): $\mathrm{mp} .152-153{ }^{\circ} \mathrm{C} ;[\alpha]^{25}{ }_{\mathrm{D}}+83.8$ (c 0.11, $\left.\mathrm{CHCl}_{3}\right)$; IR $v_{\text {max }} / \mathrm{cm}^{-1}\left(\mathrm{CHCl}_{3}\right): 2958,1774$, 1708, 1232, 1199, 925. 'H NMR ( $\left.\mathrm{CDCl}_{3}, 500 \mathrm{MHz}\right)$ and ${ }^{13} \mathrm{C}$ NMR $\left(\mathrm{CDCl}_{3}, 125 \mathrm{MHz}\right)$ : see Table 2; HRFABMS $[\mathrm{M}+\mathrm{H}]^{+}$Found: 265.1805. Calc. for $\mathrm{C}_{16} \mathrm{H}_{24} \mathrm{O}_{3}+\mathrm{H}: 265.1804$; EIMS m/z 264 (17\%), 205 (86), 55(69), 43 (100).

3-Keto-15-hydroxysclareolide (18): mp. $169-171{ }^{\circ} \mathrm{C}$; $[\alpha]_{\mathrm{D}}^{25}+29.3($ c $0.20, \mathrm{MeOH}) ; \mathrm{IR} v_{\max } / \mathrm{cm}^{-1}\left(\mathrm{CHCl}_{3}\right): 3459$, 2985, 2952, 1773, 1698, 1431, 1234, 1174, 920; ${ }^{1} \mathrm{H}$ NMR $\left(\mathrm{CDCl}_{3}, 500 \mathrm{MHz}\right)$ and ${ }^{13} \mathrm{C} \mathrm{NMR}\left(\mathrm{CDCl}_{3}, 125 \mathrm{MHz}\right)$ : see Table 2; HRFABMS $[\mathrm{M}+\mathrm{H}]^{+}$Found: 281.1751. Calc. for $\mathrm{C}_{16} \mathrm{H}_{24} \mathrm{O}_{4}+\mathrm{H}$ : 281.1753); EIMS m/z 280 (12\%), 278 (36), 277 (11), 250 (67), 235 (48), 81 (41), 43 (100).

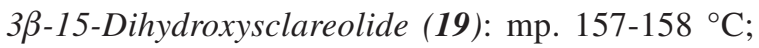
$[\alpha]^{25}{ }_{\mathrm{D}}+49.2$ ( c $\left.0.13, \mathrm{MeOH}\right) ; \mathrm{IR} v_{\max } / \mathrm{cm}^{-1}\left(\mathrm{CHCl}_{3}\right): 3489$, 2944, 1767, 1603,1457, 1349, 1243, 920. ${ }^{1} \mathrm{H}$ NMR $\left(\mathrm{CDCl}_{3}\right.$, $500 \mathrm{MHz})$ and ${ }^{13} \mathrm{C} \mathrm{NMR}\left(\mathrm{CDCl}_{3}, 125 \mathrm{MHz}\right)$ : see Table 2. HRFABMS [M+H] ${ }^{+}$Found: 283.1908. Calc. for $\mathrm{C}_{16} \mathrm{H}_{26} \mathrm{O}_{4}+\mathrm{H}$ : 283.1909; EIMS m/z 282 [M+, 20\%], 264 [ $\left.\mathrm{M}^{+}-\mathrm{H}_{2} \mathrm{O}, 41\right], 251$ 
(57), $233(56), 181$ (12), 173 (30) 147 (69), 121 (64), 93 (52), 81 (41), 43 (100), 18 (36).

\section{Biotransformation of $\mathbf{1}$ by C. blackesleeana in medium B}

The substrate 1 (307.5 mg) was dissolved in acetone $(15 \mathrm{~mL})$, distributed among 20 erlenmeyer flask cultures (medium B), previously inoculated (72 h) with a dense suspension of spores of $C$. blackesleeana. The fermentation was allowed to proceed for 14 days, the cultures were processed as indicated above to obtain starting material 1 (16.3 mg, 5.3\%), 2 (22.3, 7.2\%), 4 (63.4 mg, 20.6\%), $3 \alpha, 6 \beta$-dihydroxysclareolide $(\mathbf{1 6}, 86.9 \mathrm{mg}, 28.3 \%)$ and 1-ketosclareolide (17, $26.7 \mathrm{mg}, 8.7 \%)$.

Biotransformation of $\mathbf{1}$ by C. lunata, B. bassiana, R. oligosporus, R. nigricans, M. miehei and F. moliniforme

Compound 1 $(150 \mathrm{mg}$ ) was reacted with the microorganisms following the procedure described above, obtaining the results shown in Table 1.

\section{Cytotoxic assays}

Human tumor cell lines of central nervous system (U251), prostate cancer (PC-3), leukemia (K562), colon (HCT-15), breast (MCF-7), lung (SKLU-1) were supplied by the National Cancer Institute (NCI). The cytotoxic activities of 1, 2, 4, 16-19 were determined using the protein-binding dye sulforhodamine $\mathrm{B}$ in a microculture assay to measure cell growth, following the protocols described in the literature. ${ }^{18}$ Results were expressed as concentration giving 50\% inhibition $\left(\mathrm{IC}_{50}\right)$. The $\mathrm{IC}_{50}$ values (mean \pm standard error) were $100 \mu \mathrm{M}$, and those with minor values are reported in the text. The positive control was adriamycin $\left(\mathrm{IC}_{50}=0.32 \pm 0.02 \mu \mathrm{M}\right.$ against $\left.\mathrm{U} 251\right)$.

\section{Supplementary Information}

Supplementary information data are available free of charge at http://jbcs.org.br as a PDF file.

\section{Acknowledgments}

The autors thank Rocío Patiño, Beatriz Quiroz, Angeles Peña, María Isabel Chávez, Luis Velasco, Javier Pérez and Antonio Nieto from the Instituto de Química, UNAM for technical assistence. Financial supports from Consejo Nacional de Ciencia y Tecnología (Project 102158), Dirección General de Asuntos del Personal Académico, UNAM and Carrera de Biología, Facultad de Estudios Superiores Zaragoza, UNAM, are gratefully acknowledged.

\section{References}

1. Panke, S.; Wubbolts, M.; Curr. Opin. Chem. Biol. 2005, 9, 188.

2. Huisman, G. W.; Gray, D.; Curr. Opin. Biotechnol. 2002, 13, 352.

3. Straathof, A. J. J.; Panke, S.; Schmid, A.; Curr. Opin. Biotechnol. 2002, 13, 548 .

4. Davis, B. G.; Boyer, V.; Nat. Prod. Rep. 2001, 18, 1669.

5. De Raadt, A.; Herfried, G.; Curr. Opin. Biotechnol. 2002, 13, 537.

6. Zaks, A.; Curr. Opin. Chem. Biol. 2001, 5, 130.

7. Lehman, L. R.; Stewart, J. D.; Curr. Org. Chem. 2001, 5, 439.

8. Urlacher, V.; Schmid, R. D.; Curr. Opin. Biotechnol. 2002, 13, 557.

9. Van Beilen, J. B.; Duetz, W. A.; Schmid, A.; Whitholt, B.; Trends Biotechnol. 2003, 4, 170.

10. Lee, K. H.; J. Nat. Prod. 2010, 73, 500.

11. León, A.; Reyes, B. M.; Chávez, M. I.; Toscano, R. A.; Delgado, G.; J. Mex. Chem. Soc. 2009, 53, 193.

12. Upar, K. B.; Mishra, S. J.; Nalawade, S. P.; Singh, S. A.; Khandare, R. P.; Bhat, S. V.; Tetrahedron: Asymmetry 2009, 20, 1637.

13. Atta-ur-Rahman; Farooq, S.; Choudhary, M. I.; Curr. Org. Chem. 1999, 3, 309.

14. Rodríguez, E.; Towers, G. H. N.; Mitchell, J. C.; Phytochemistry 1976, 15, 1573.

15. Oh, S.; Jeong, I. H.; Shim, W. S.; Wang, Q. S.; Lee, S.; Bioorg. Med. Chem. Lett. 2006, 16, 1656.

16. Zoretic, P. A.; Fang, H.; Ribeiro, A. A.; Dubay, G.; J. Org. Chem. 1998, 63, 1156.

17. Aranda, G.; El-Korbi, M. S.; Lallermand, J. V.; Neuman, A.; Tetrahedron 1981, 47, 8339.

18. Hanson, J. R.; Truneh, A.; Phytochemistry 1996, 42, 1021.

19. Atta-ur-Rahman; Farooq, A.; Choudhary, M. I.; J. Nat. Prod. 1997, 60, 1038.

20. Choudhary, M. I.; Musharraf, S. G.; Sami, A.; Atta-ur-Rahman; Helv. Chem. Acta 2004, 87, 2685.

21. Ata A.; Conci, L. J.; Betteridge, J.; Orhan, I.; Sener, B.; Chem. Pharm. Bull. 2007, 55, 118.

22. Pelletier, S. W.; Chokshi, H. P.; Desai, H. K.; J. Nat. Prod. 1986, 49, 892.

23. Coll, J. C.; Bowden, B. F.; J. Nat. Prod. 1986, 49, 934.

24. García Granados, A.; Martínez, A.; Parra, A.; Rivas, F.; Curr. Org. Chem. 2007, 11, 679.

25. Monks, A.; Seudiero, D.; Skehan, P.; Shoemaker, R.; Paull, K.; Vistica, D.; Hose, C.; Langley, J.; Cronise, P.; Vaigro-Wolff, A.; Gray-Goodrich, M.; Campbell, H.; Mayo, J.; Boyd, M.; J. Nat. Cancer Inst. 1991, 83, 753.

Submitted: March 30, 2010 Published online: February 24, 2011 


\section{Biotransformation of Sclareolide by Filamentous Fungi: Cytotoxic Evaluations of the Derivatives}

\section{Arturo Cano, ${ }^{a}$ María Teresa Ramírez-Apan ${ }^{b}$ and Guillermo Delgado ${ }^{*, b}$}

${ }^{a}$ Facultad de Estudios Superiores Zaragoza, Universidad Nacional Autónoma de México, Av. Guelatao $n^{\circ} .66$ (Eje 7 Oriente), Col Ejército de Oriente, Iztapalapa 09230, Mexico, D.F.

${ }^{b}$ Instituto de Química, Universidad Nacional Autónoma de México, Ciudad Universitaria, Circuito Exterior, Coyoacán 04510, Mexico, D.F.<smiles>CC1(F)C(O)CCC2C1C(O)CC1(C)OC(=O)C[C@]21C</smiles>

(16)

H.6

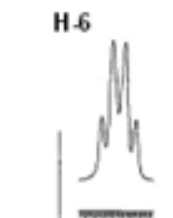

ppm

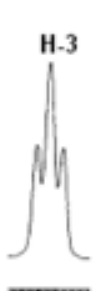

ppe
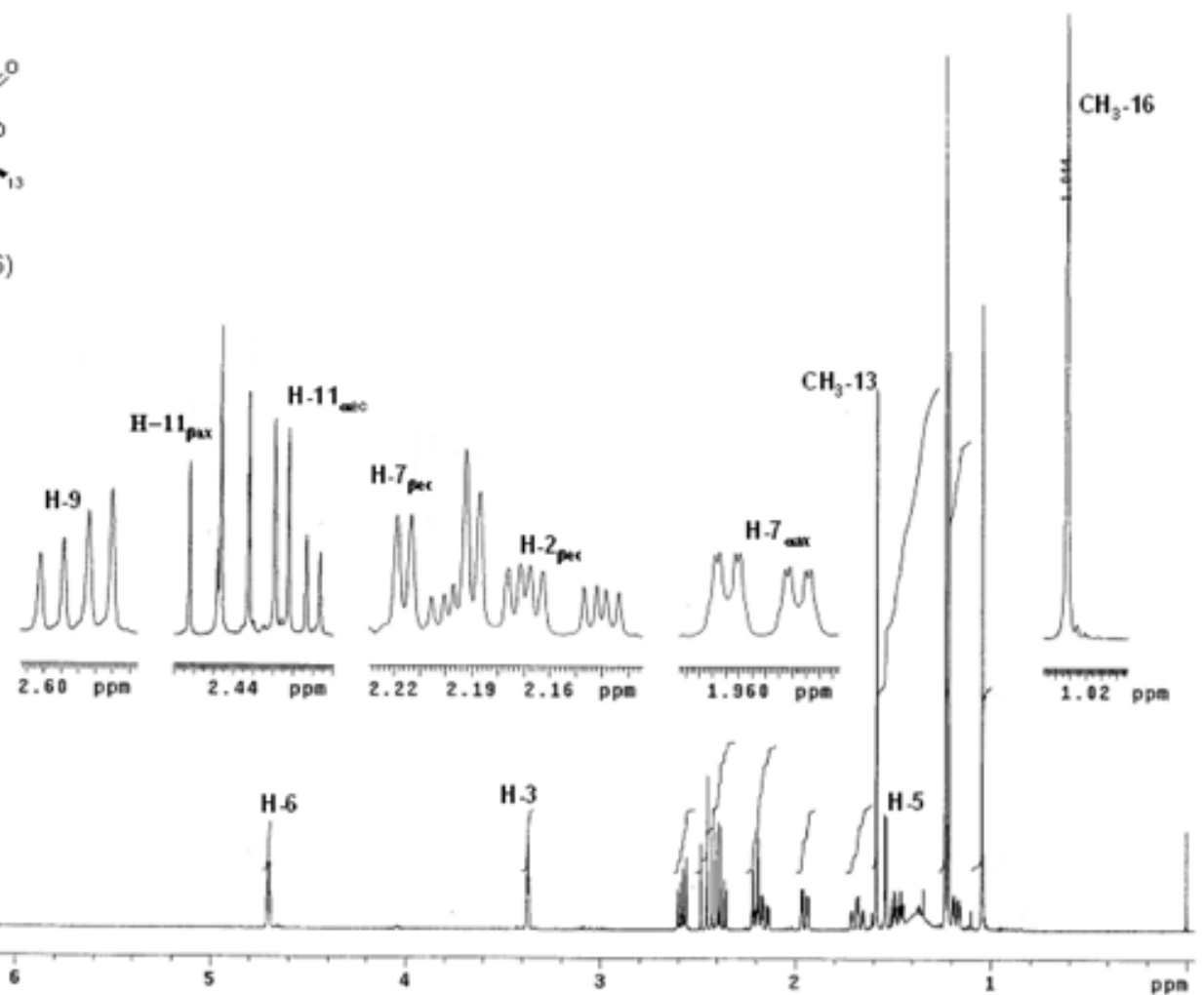

Figure S1. ${ }^{1} \mathrm{H}$ NMR $\left(500 \mathrm{MHz}, \mathrm{CDCl}_{3}\right)$ of $3 \alpha, 6 \beta$-dihydroxysclareolide (16). 

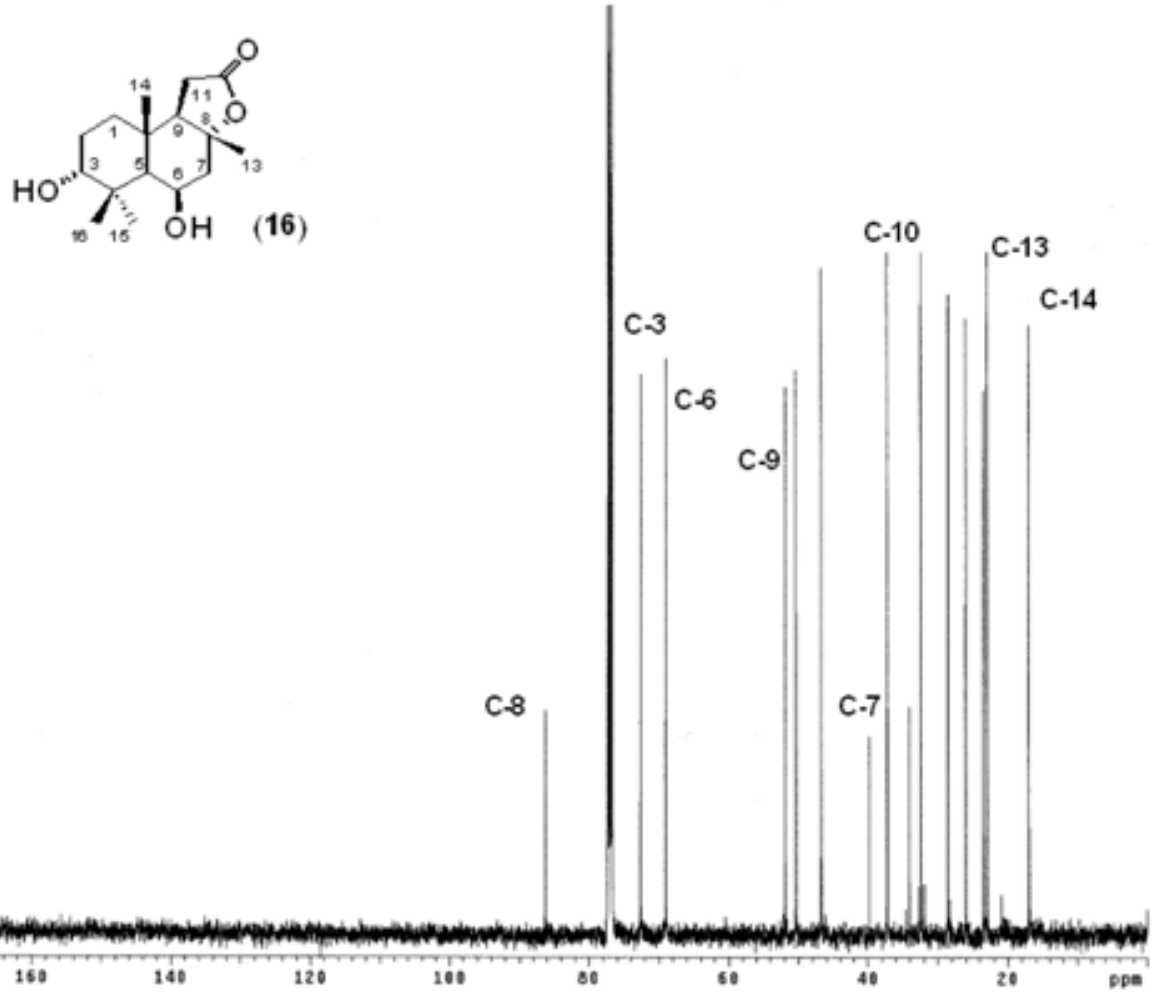

Figure S2. ${ }^{13} \mathrm{C}$ NMR $\left(125 \mathrm{MHz}, \mathrm{CDCl}_{3}\right)$ of $3 \alpha, 6 \beta$-dihydroxysclareolide (16).

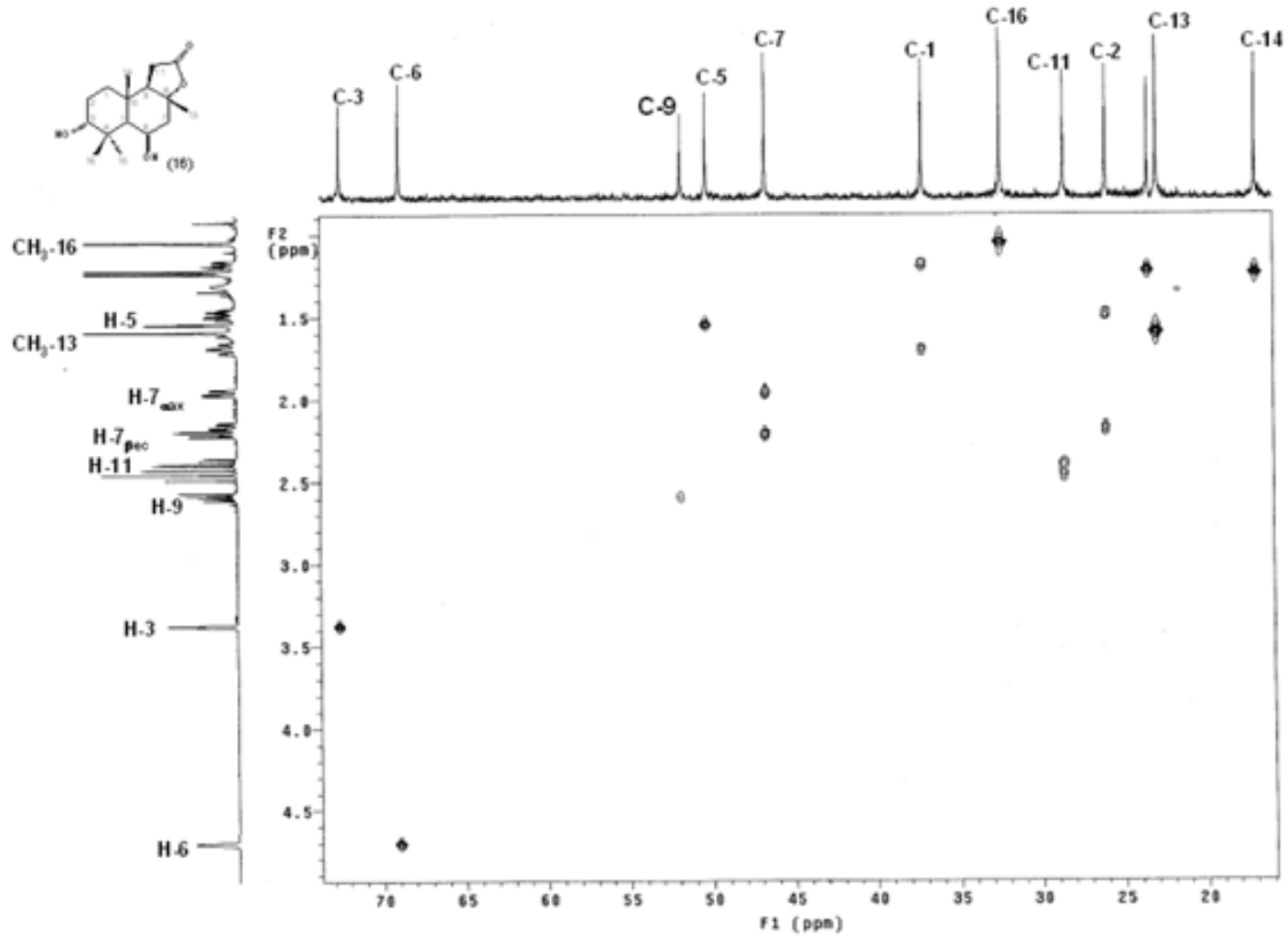

Figure S3. HSQC (500 MHz, $\mathrm{CDCl}_{3}$ ) of $3 \alpha, 6 \beta$-dihydroxysclareolide (16). 


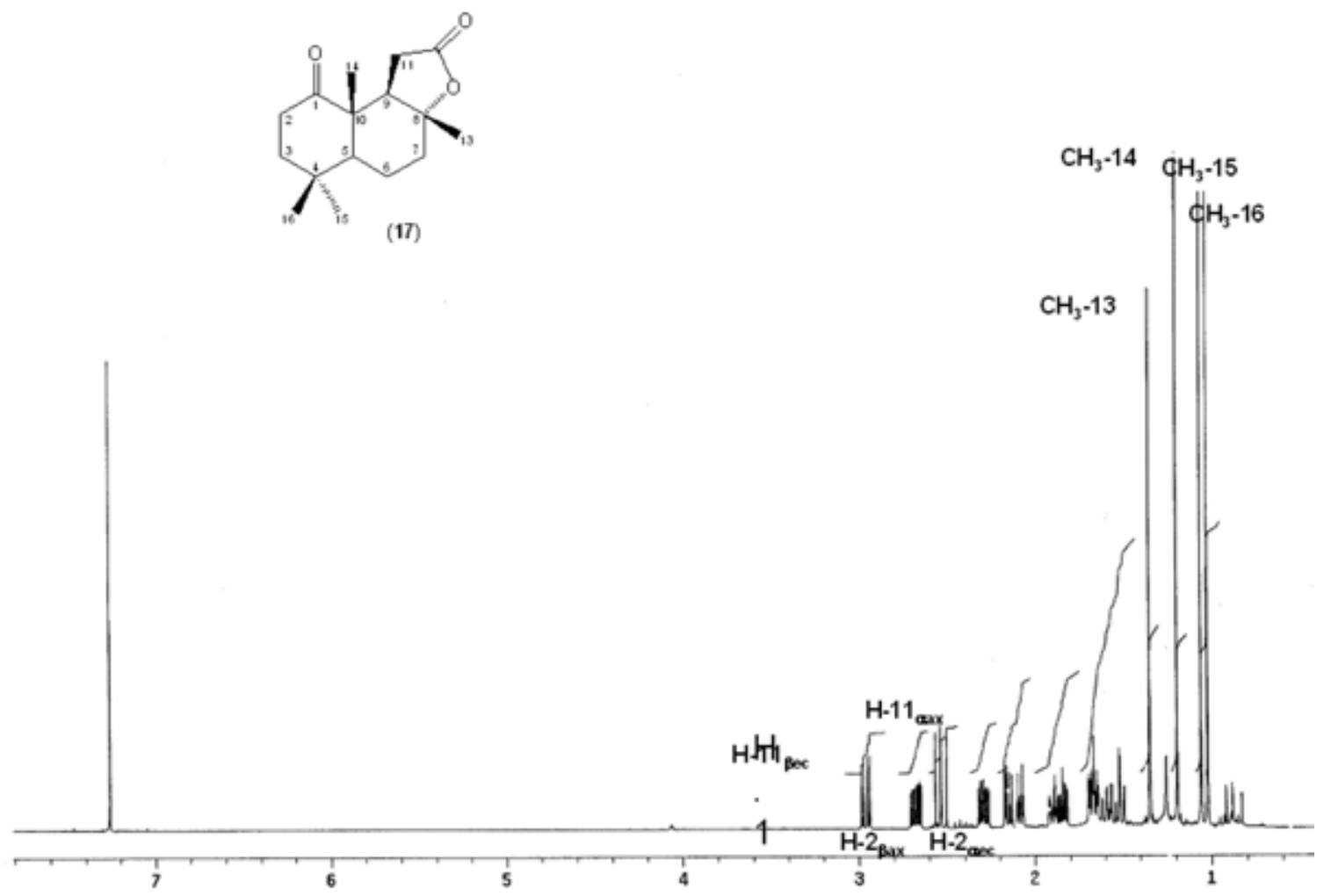

Figure S4. ${ }^{1} \mathrm{H}$ NMR (500 MHz, $\mathrm{CDCl}_{3}$ ) of 1-ketosclareolide (17).
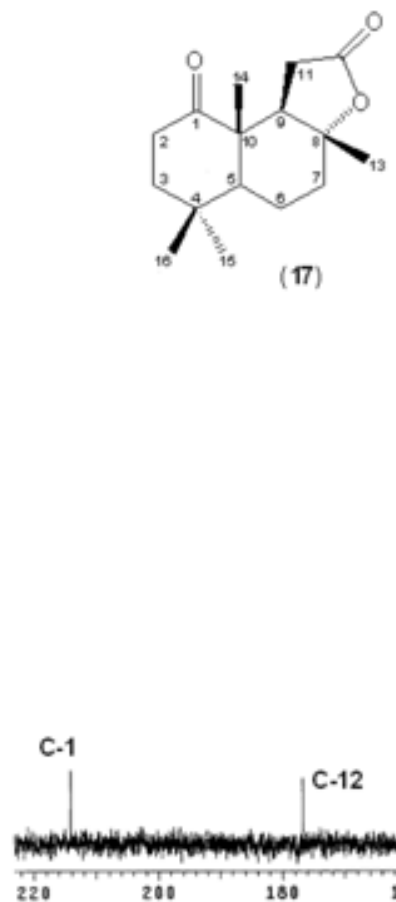

C-12

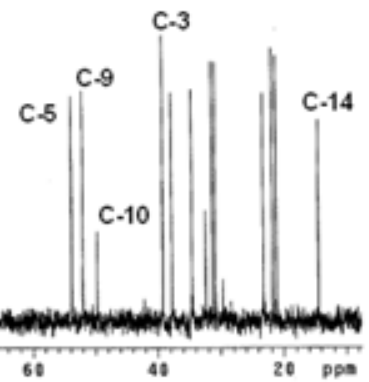

Figure S5. ${ }^{13} \mathrm{C}$ NMR $\left(125 \mathrm{MHz}, \mathrm{CDCl}_{3}\right)$ of 1-ketosclareolide (17). 


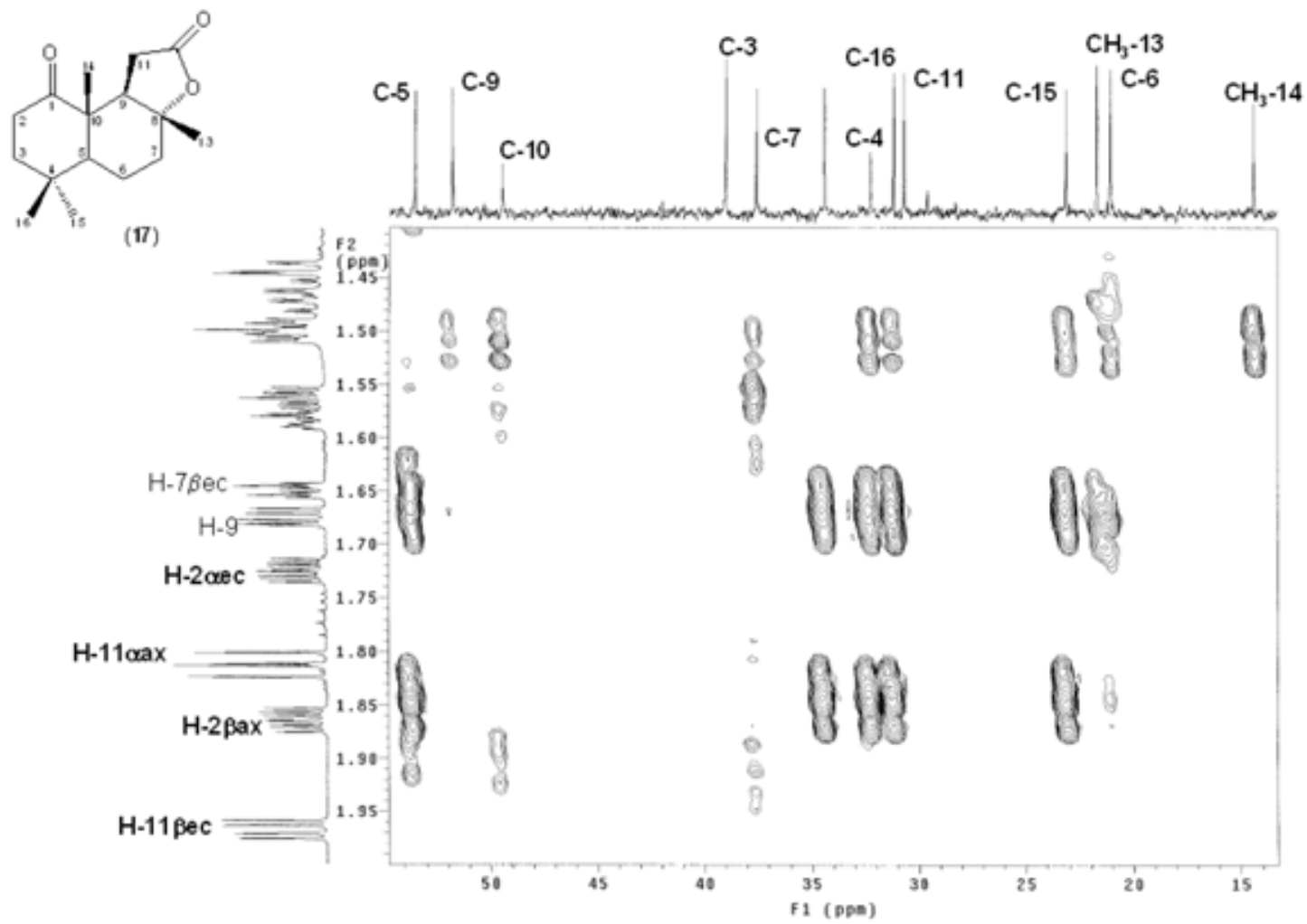

Figure S6. HMBC (500 MHz, $\mathrm{CDCl}_{3}$ ) of 1-ketosclareolide (17).
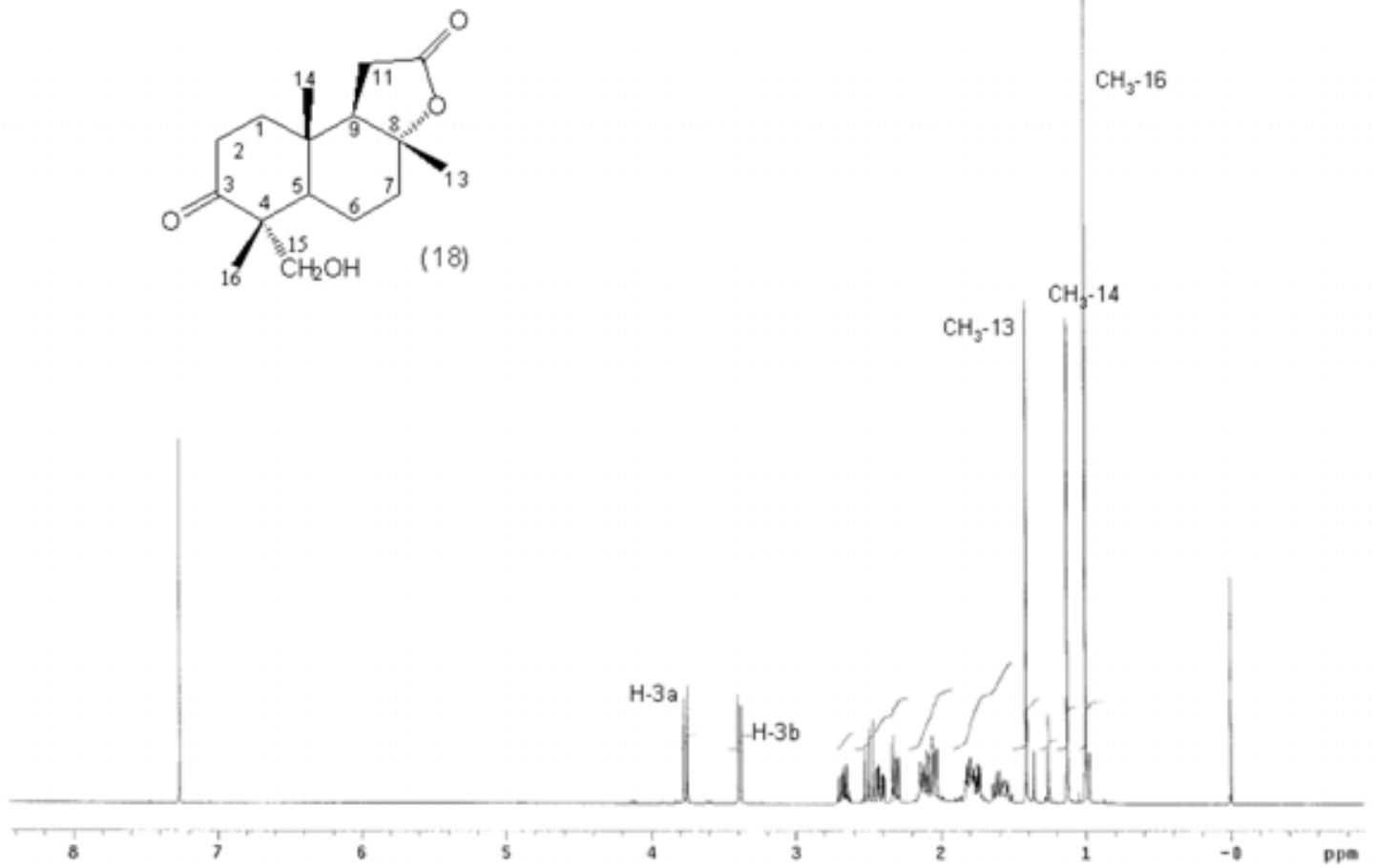

Figure S7. ${ }^{1} \mathrm{H}$ NMR (500MHz, $\mathrm{CDCl}_{3}$ ) of 3-keto-15-hydroxysclareolide (18). 

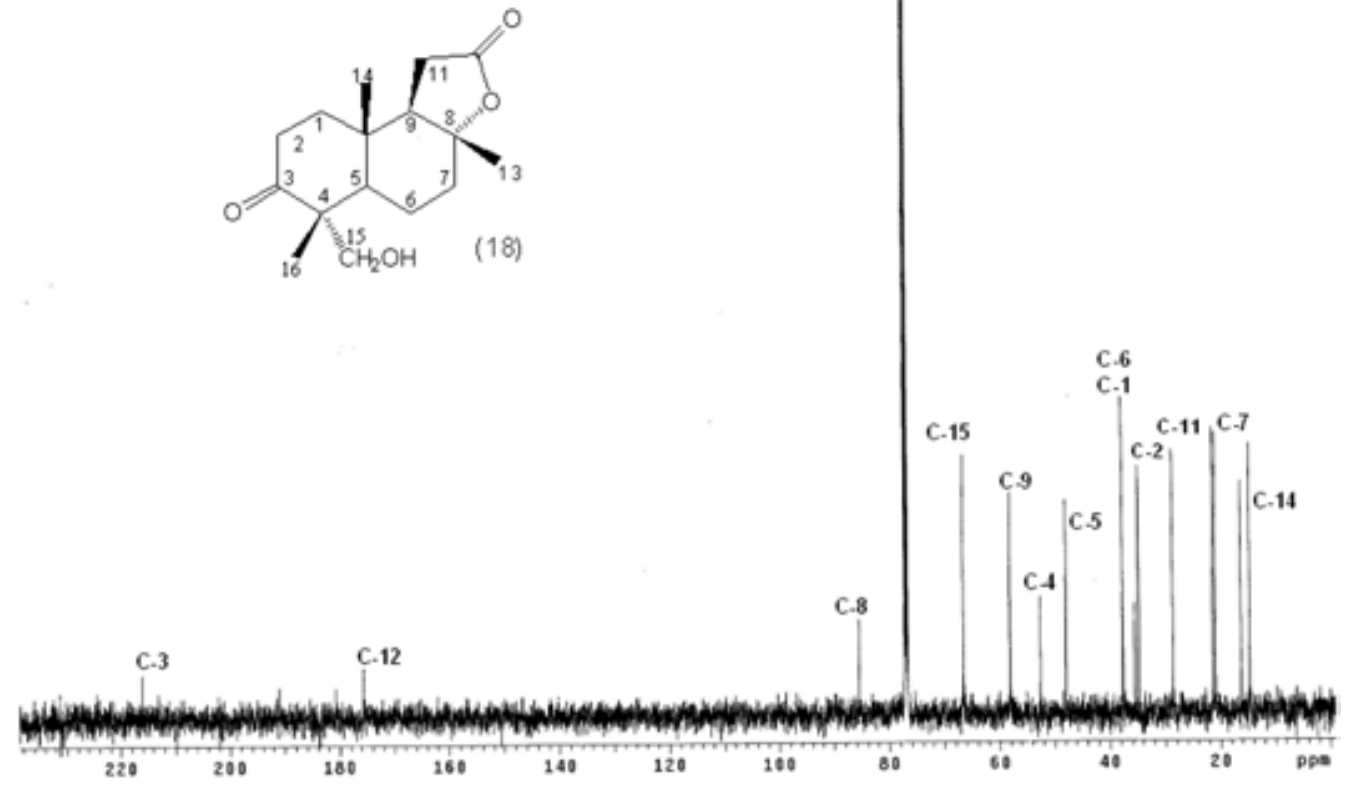

Figure S8. ${ }^{13} \mathrm{C}$ NMR (125 MHz, $\mathrm{CDCl}_{3}$ ) of 3-keto-15-hydroxysclareolide (18).

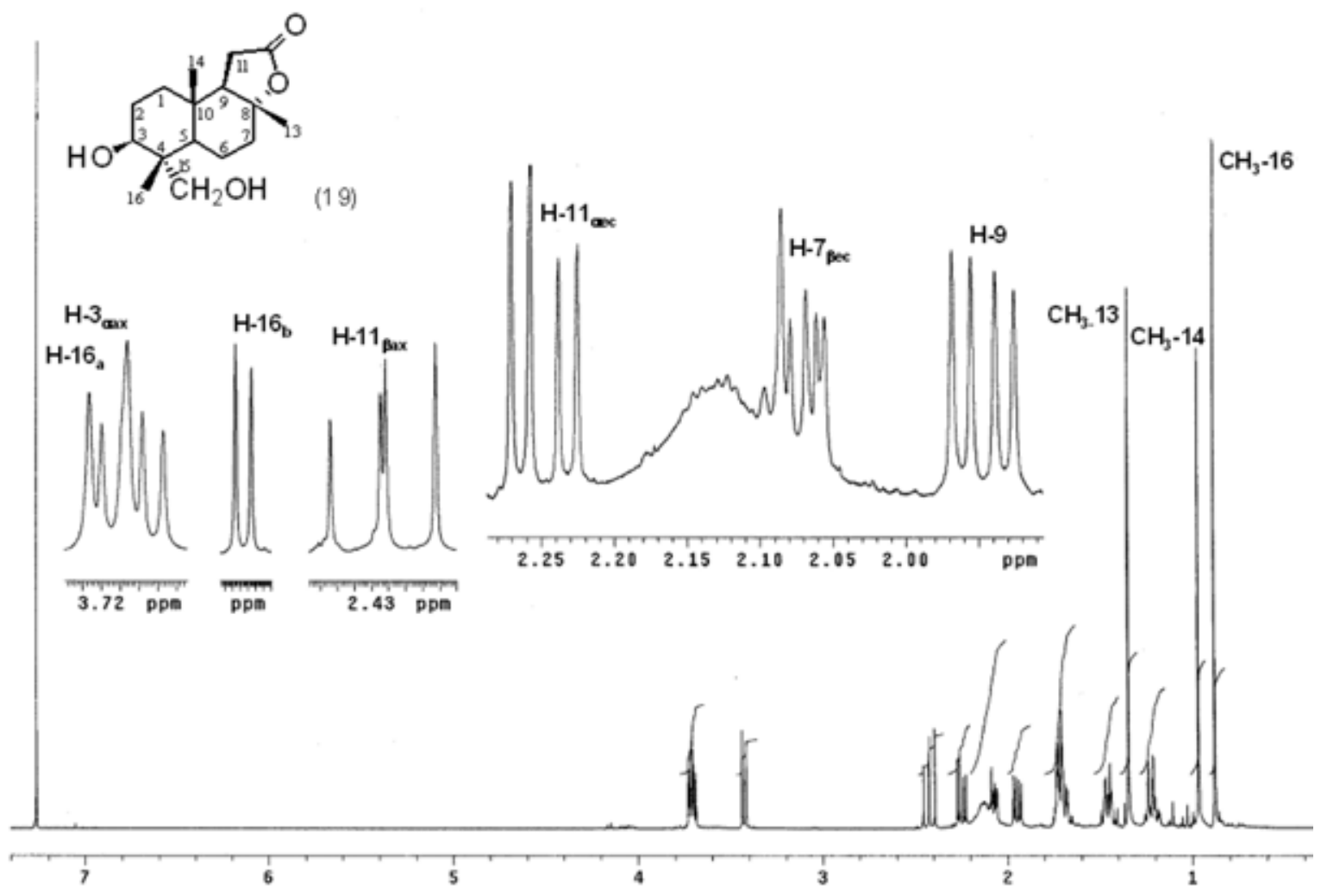

Figure S9. ' $\mathrm{H}$ NMR (500 MHz, $\mathrm{CDCl}_{3}$ ) of 3 $\beta$,15-dihydroxysclareolide (19). 

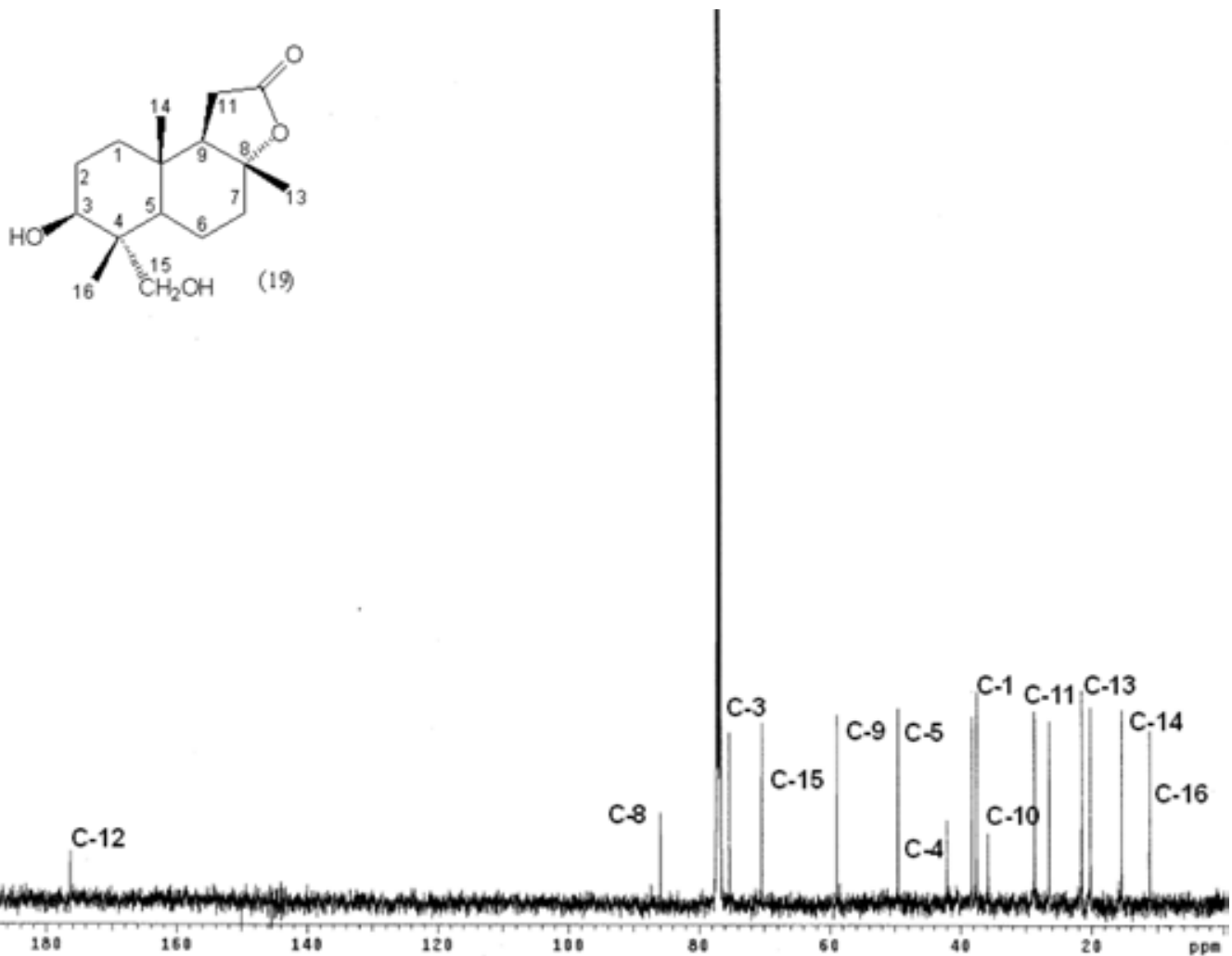

Figure S10. ${ }^{13} \mathrm{C}$ NMR $\left(125 \mathrm{MHz}, \mathrm{CDCl}_{3}\right)$ of 3 $\beta, 15$-dihydroxysclareolide (19).

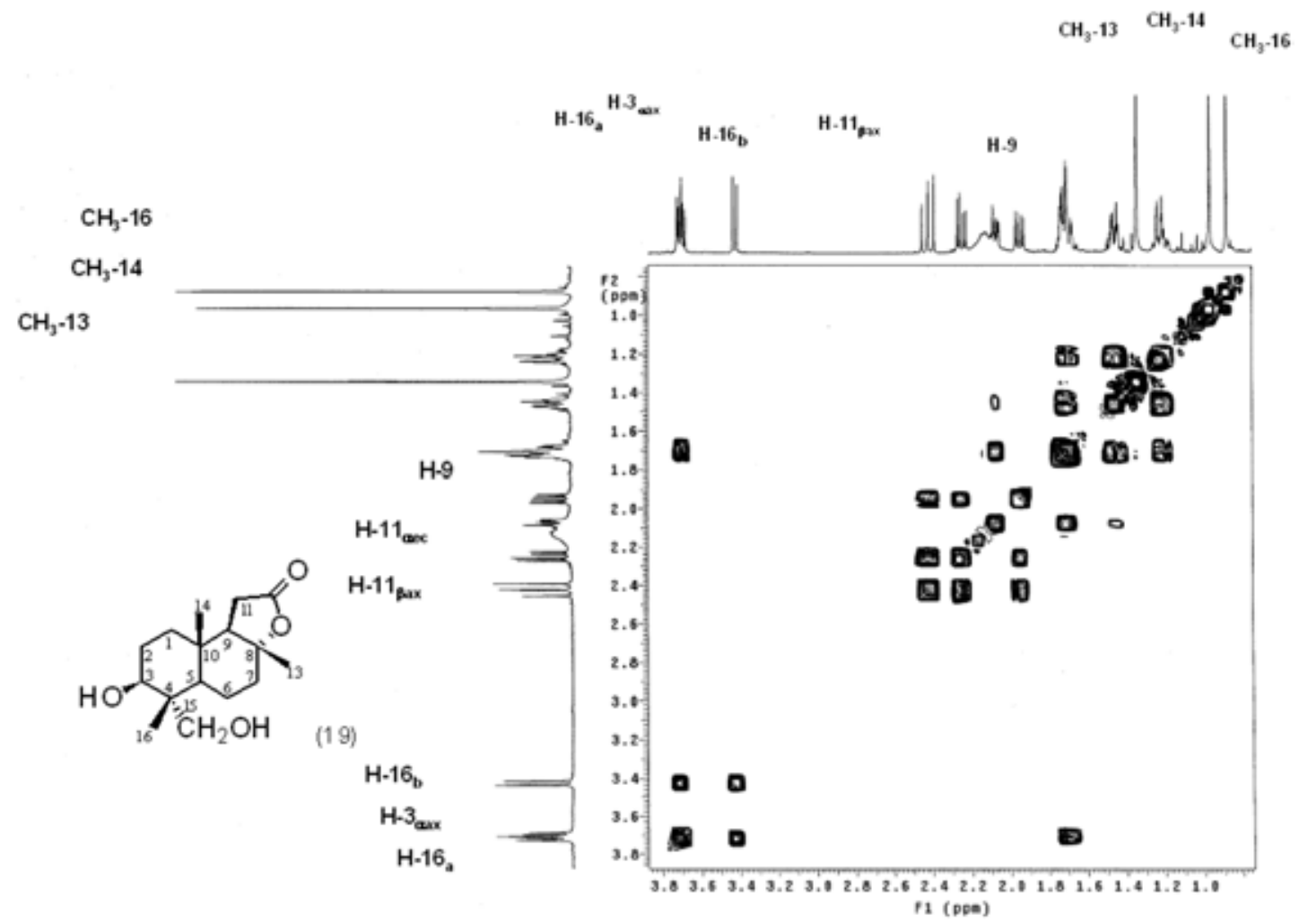

Figure S11. COSY Spectrum (500 MHz, $\mathrm{CDCl}_{3}$ ) of 3ß,15-dihydroxysclareolide (19). 


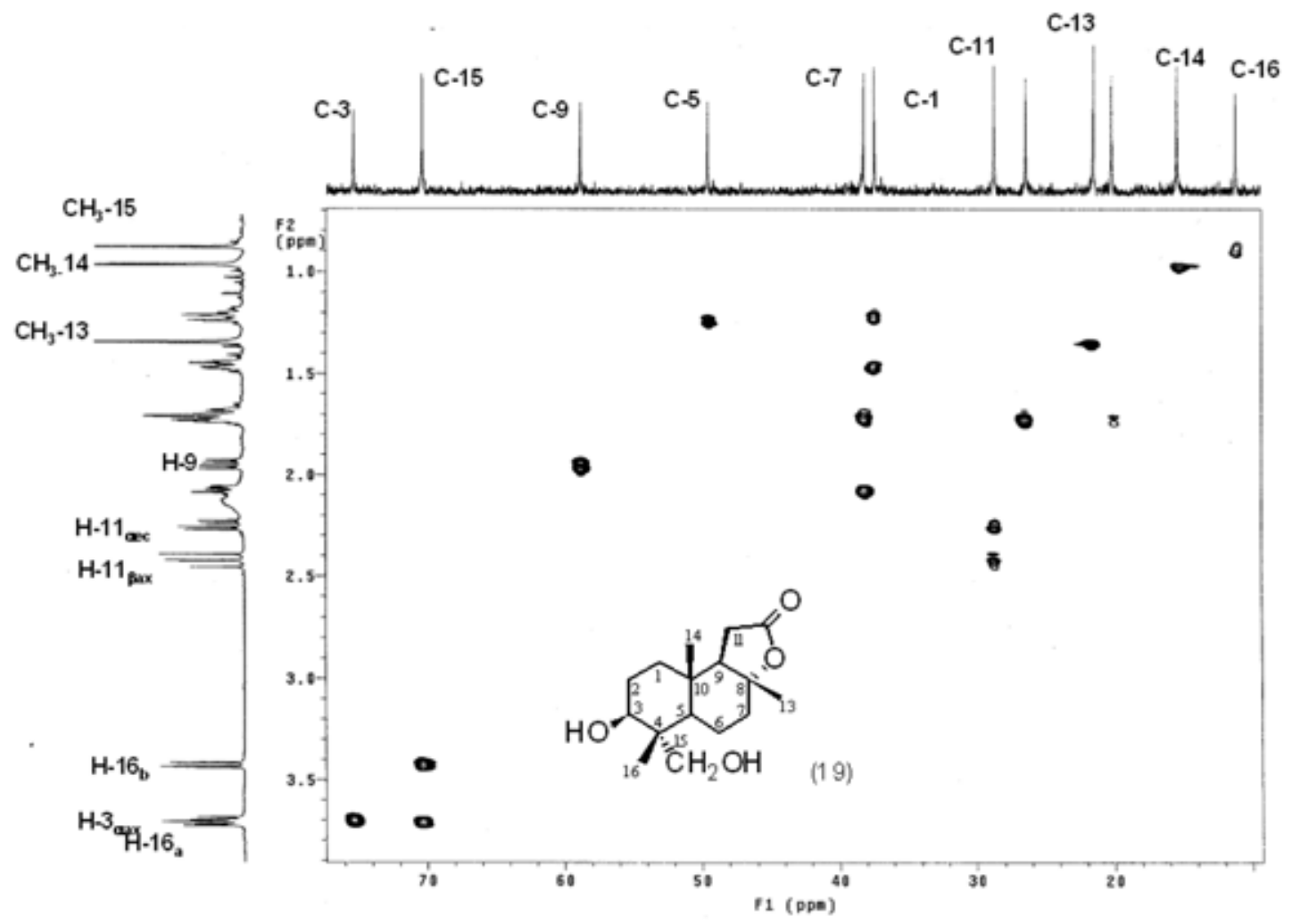

Figure S12. HSQC (500 MHz, $\mathrm{CDCl}_{3}$ ) of 3ß,15-dihydroxysclareolide (19). 